\title{
Note
}

\section{Seasonal Changes in Horizontal Distribution of Algal Picoplankton in Lake Biwa with Special Reference to Water Temperature, Nutrient Levels and Heterotrophic Flagellates}

\author{
Shin-ichi NaKano, Katsumi TanaKa, Tadashi Sono, Tetsuya WaKabayashi, \\ Satoshi Ichise, Sunao Yamanaka, Emiko Kaneda, Minoru Yada, \\ Mikishige NaIToH, Koichi Kawabe, Kayo Maehata, Naoki Fujiwara, \\ Noriko MaEdA, Kiyoshi Nomura and Masami NaKanishI
}

\begin{abstract}
Seasonal changes in the horizontal distributions of algal picoplankton (APP) were examined in relation to those of heterotrophic flagellates and some environmental factors at 8 sampling stations covering both the northern and southern basins of Lake Biwa from June 1992 to March 1993. Water temperature and nutrient levels differed little among these stations. Horizontal distribution of APP was variable during the summer and fall. There was a consistent trend in the changing pattern of APP density at each station : cell density of APP at all stations was highest in August and low during the winter. Horizontal distributions of both flagellates and APP were changeable during the summer and fall. However, we could not find a seasonal trend in the changing pattern of flagellate density at each station.
\end{abstract}

Key words : algal picoplankton, horizontal distribution, heterotrophic flagellates, Lake Biwa

Algal picoplankton (APP) may account for a large portion of phytoplankton biomass and primary production in lake and marine ecosystems (STOCKNER and ANTIA, 1986). Previous studies have suggested that nutrient levels (SUTTLE and HARRISON, 1988; WHER, 1989) and grazing activity (NAGATA, 1988 ; WEISSE, 1988) greatly affect the dynamics of APP in lakes. Among gtazers, heterotrophic flagellates have been considered one of the most important grazers of APP (NAGATA, 1988).

APP have been investigated in Lake Biwa, the largest lake in Japan (surface area 674 $\mathrm{km}^{2}$ ). Data have suggested that APP are important as a primary producer (NAGATA, 1986, 1988; ICHISE et al., 1991; MAEDA et al., 1992). An extremely high density of APP (maximum $4.6 \times 10^{6}$ cells $\cdot \mathrm{ml}^{-1}$ ) has been observed in this lake (ICHISE et al., 1991). However, little is known about the horizontal distribution of APP and its relation with environmental conditions such as nutrients, temperature and grazing pressure.

The purpose of this study was to examine seasonal changes in the horizontal distribution of APP, nutrients and flagellates for a better understanding of the dynamics of the microbial food web in Lake Biwa.

We staffed eight sampling stations covering both the deep North Basin (mean depth $44 \mathrm{~m}$, surface area $616 \mathrm{~km}^{2}$ ) and the shallow South Basin (mean depth $3.5 \mathrm{~m}$, surface area $58 \mathrm{~km}^{2}$ ) (Fig. 1). Samples were collected monthly from June 1992 to March 1993. Water samples were collected with a Van Dorn water sampler at a $0.5 \mathrm{~m}$ depth. Water temperature was measured with a thermistor thermometer.

A portion of water samples was filtered 
through Whatman GF/F glass fiber filters. The filtrate was used for chemical analyses. Concentrations of ammonium $\left(\mathrm{NH}_{4}-\mathrm{N}\right)$, nitrite $\left(\mathrm{NO}_{2}\right.$. $\mathrm{N})$ and nitrate $\left(\mathrm{NO}_{3}-\mathrm{N}\right)$ nitrogen were determined by the methods of BOwER and HoLMHANSEN (1980), BENDSCHNEIDER and RoBinson (1952) and WOOD et al. (1967), respectively. The concentration of dissolved inorganic phosphorus (DIP) was determined by the method of MurPhy and Riley (1962).

A portion of water samples was brought to the laboratory within 3-4 hours under cool and dark conditions, and used for the enumeration of APP. Subsamples were mounted on a Sekisui microscopic plate (Sekisui Co., Ltd., Osaka), which is a commercially available slide glass with five grids covered with a cover glass. The size of each grid is $12(\mathrm{~L}) \times 10(\mathrm{~W}) \times 0.07(\mathrm{D})$ $\mathrm{mm}$, equal to $0.0084 \mathrm{ml}$ volume. The number of APP in each grid was counted under an epifluorescence microscope (Nikon OPTIPHOT, $G$ excitation EFDA2 DM 580, magnification $\times 400$ ). The enumeration for one water sample was conducted within one grid until 400 cells of APP were counted. We, how.

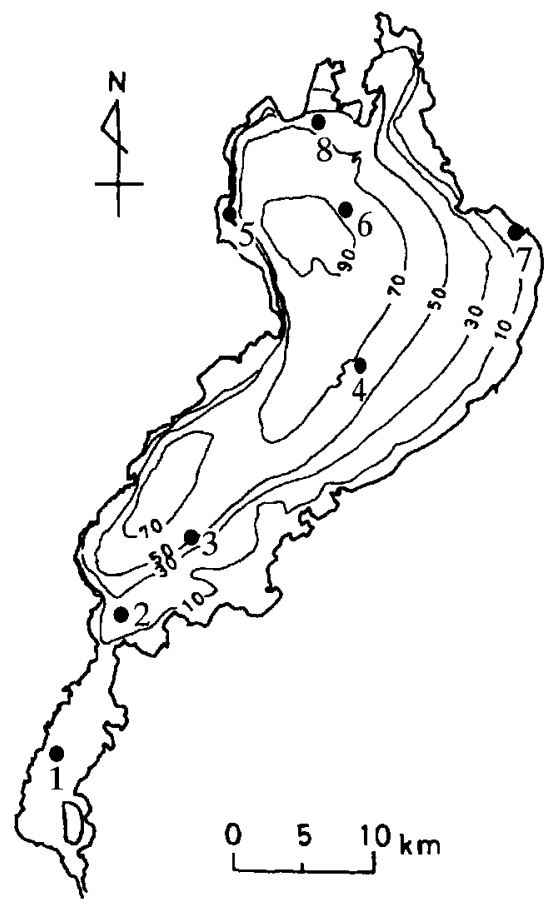

Fig. 1. Sampling stations in Lake Biwa. ever, could enumerate only about 100 cells of APP from November to March, since APP numbers were very low during winter. Coefficient of variation was $14.5 \%$ for this method.

On shipboard, samples for enumeration of heterotrophic flagellates were fixed with glutaraldehyde (final concentration, 1\%). Flagellates were counted by the fluorescein isothiocyanate (FITC) staining method (SHERR and SHERr, 1983) with slight modifications (NAKANO et al., 1993).

At all stations, water temperature increased from June $\left(c a .20^{\circ} \mathrm{C}\right)$ to September $\left(c a .27^{\circ} \mathrm{C}\right)$ and, thereafter, steadily decreased to $8.3^{\circ} \mathrm{C}$ during the study period (Fig. 2). A changing pattern of concentrations of dissolved inorganic

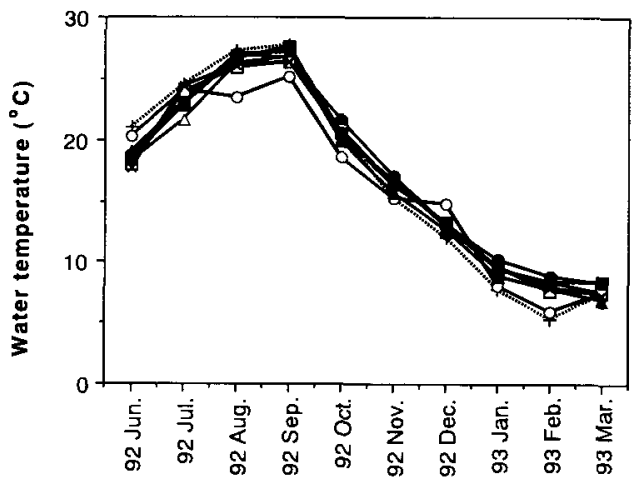

Fig. 2. Seasonal changes in water temperature during the survey period at stations in Lake Biwa. Symbols indicating stations --+--, $1 ; \bigcirc, 2 ; \mathbf{O}, 3 ; \triangle, 4 ; \Delta, 5 ; \square, 6 ; \square, 7 ; \times, 8$.

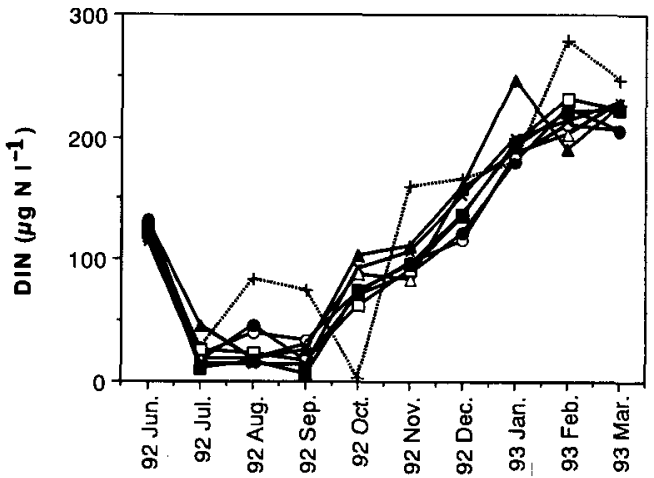

Fig. 3. Seasonal changes in concentrations of dissolved inorganic nitrogen (DIN) during the survey period at stations in Lake Biwa. Symbols are the same as Fig. 2. 

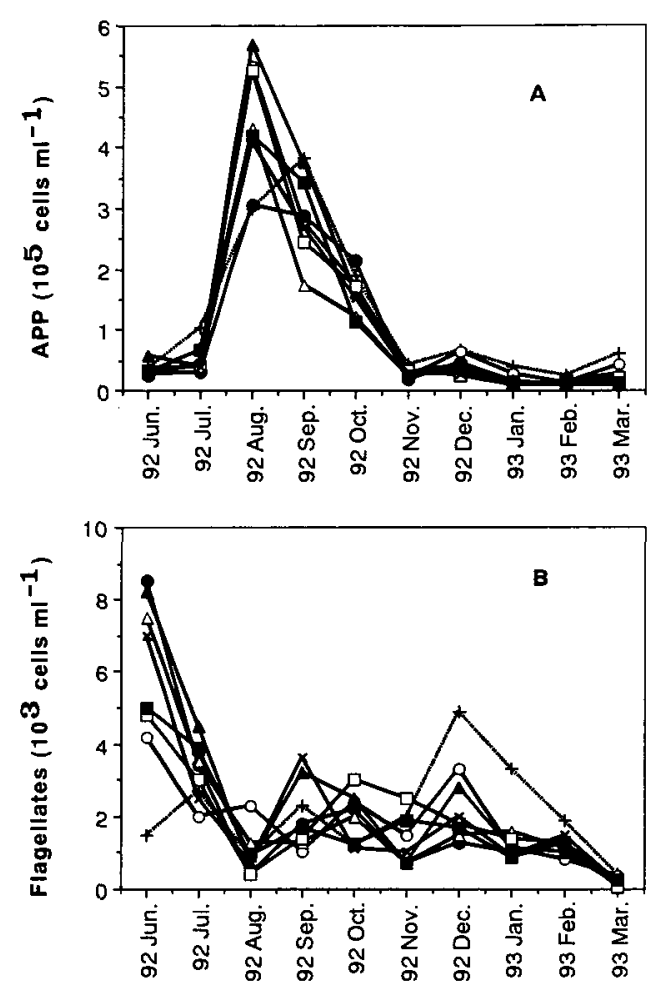

Fig. 4. Seasonal changes in cell densities of algal picoplankton (APP) (A) and heterotrophic flagellates (B) during the survey period at stations in Lake Biwa. Symbols are the same as in Fig. 2.

nitrogen $\left(\mathrm{DIN}=\mathrm{NO}_{3}-\mathrm{N}+\mathrm{NO}_{2}-\mathrm{N}+\mathrm{NH}_{4}-\mathrm{N}\right)$ at each station was generally the same among all stations (Fig. 3). DIN concentrations decreased down to $<50 \mu \mathrm{g} \mathrm{N} \cdot 1^{-1}$ in July and continued low until September. Thereafter, DIN concentrations increased substantially, probably because of the vertical transport of nitrate accumulated in the hypolimnion of the North Basin (TEZUKA, 1984). Concentrations of DIP at each station was mostly below the detection limit $\left(<1.0 \mu \mathrm{g} P \cdot 1^{-1}\right)$ throughout the study period (data not shown).

Seasonal changing patterns of cell densities of APP (Fig, 4A) differed little among sampling stations. At all stations, the maximum APP cell densities were observed in either August or September when water temperature was the highest. The maximum density was variable depending on stations, ranging from 3.0 to $5.7 \times$ $10^{5}$ cells $\cdot \mathrm{ml}^{-1}$. APP abundance decreased to
November, and the cell densities remained low $\left(<1.0 \times 10^{5}\right.$ cells $\left.\cdot \mathrm{ml}^{-1}\right)$ in winter.

Horizontal distributions of cell densities of APP (Fig. 5) demonstrated that the distribution was seasonally variable from June to October 1992. However, in winter (November 1992 to March 1993), APP density in the South Basin (Station 1) tended to be higher than that at other stations.

Cell densities of heterotrophic flagellates were relatively high in June 1992 (4.2 to $8.5 \times$ $\left.10^{3} \mathrm{cells} \cdot \mathrm{ml}^{-1}\right)$ at all the stations except Station 1 (Fig. 4B). The densities decreased rapidly in July and fluctuated in the range $0.050-3.2 \times 10^{3}$ cells $\cdot \mathrm{ml}^{-1}$ thereafter. At Station 1 , cell density of flagellates fluctuated from 0.40 and $4.9 \times 10^{3}$ cells $\cdot \mathrm{ml}^{-1}$. Horizontal distributions of cell densities of flagellates (Fig. 6) were similar to those of APP densities: flagellate density was horizontally variable every month from June to November 1992, and that at Station 1 was higher than those at other stations from December 1992.

From their seasonal study in 1990, ICHISE et al. (1991) have reported that APP abundance at 11 sampling stations in Lake Biwa started to increase simultaneously and attained maximum cell density in the summer. A similar seasonal pattern was observed in the present study. Summer maxima of APP abundance have been reported in other lakes (CARON et al., 1985; SøndergaARd, 1991; NAGATA et al., 1994). These studies have suggested that the seasonal dynamics of APP are controlled by several factors including temperature, light and nutrients. Besides these physical and chemical factors, we suspect that grazing pressure is another factor which greatly affects the seasonal changes of APP in Lake Biwa. In the present study, we observed that the rapid increases in cell densities of APP in August coincided with the rapid decreases in densities of flagellates (Figs. $4 \mathrm{~A}$ and $4 \mathrm{~B}$ ). The low numbers of flagellates would probably indicate low grazing pressure of flagellates on APP, which might explain the rapid increases in APP abundance in August.

Although water temperature and nutrient 


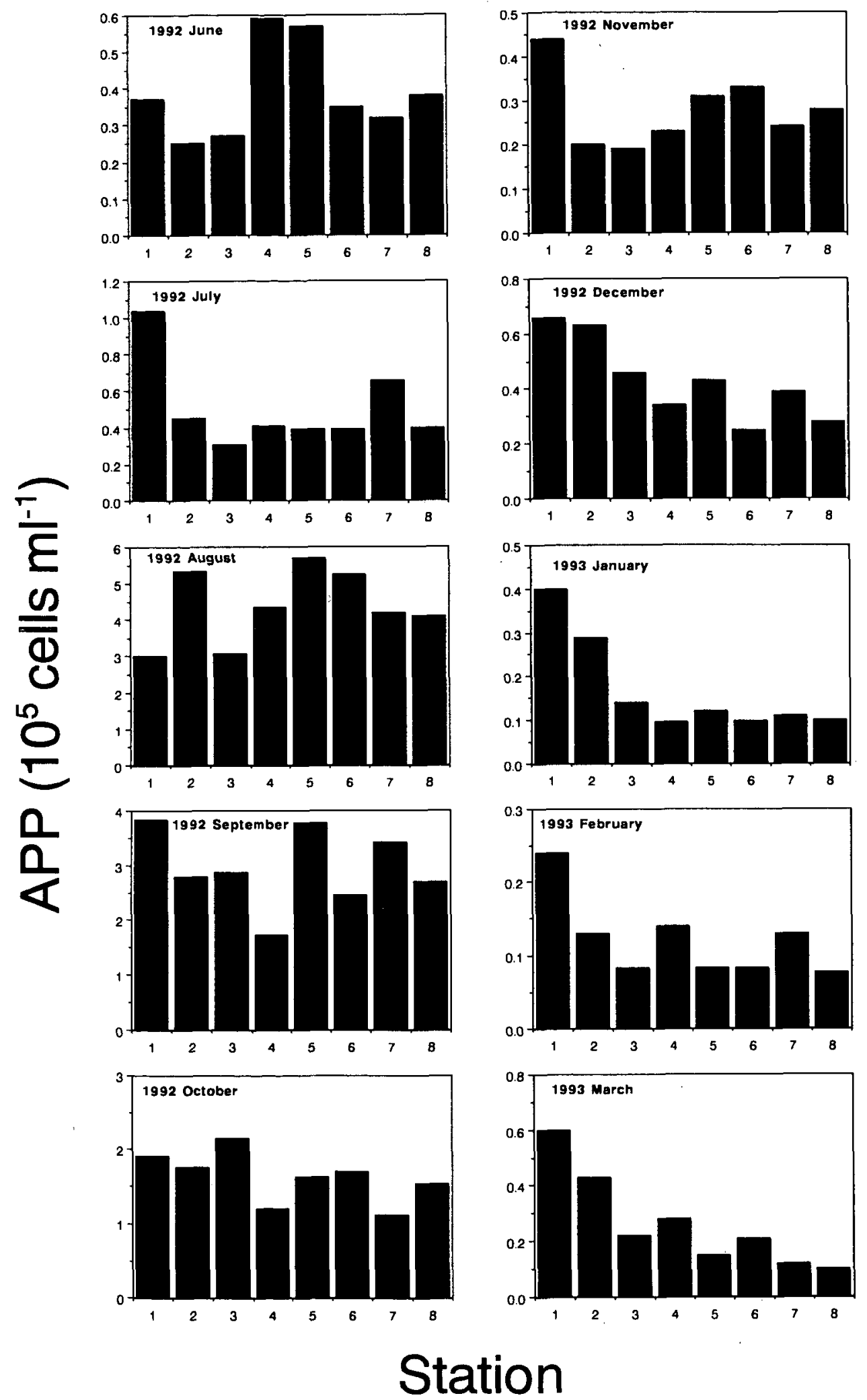

Fig. 5. Horizontal distribution of algal picoplankton (APP) during the survey period. 

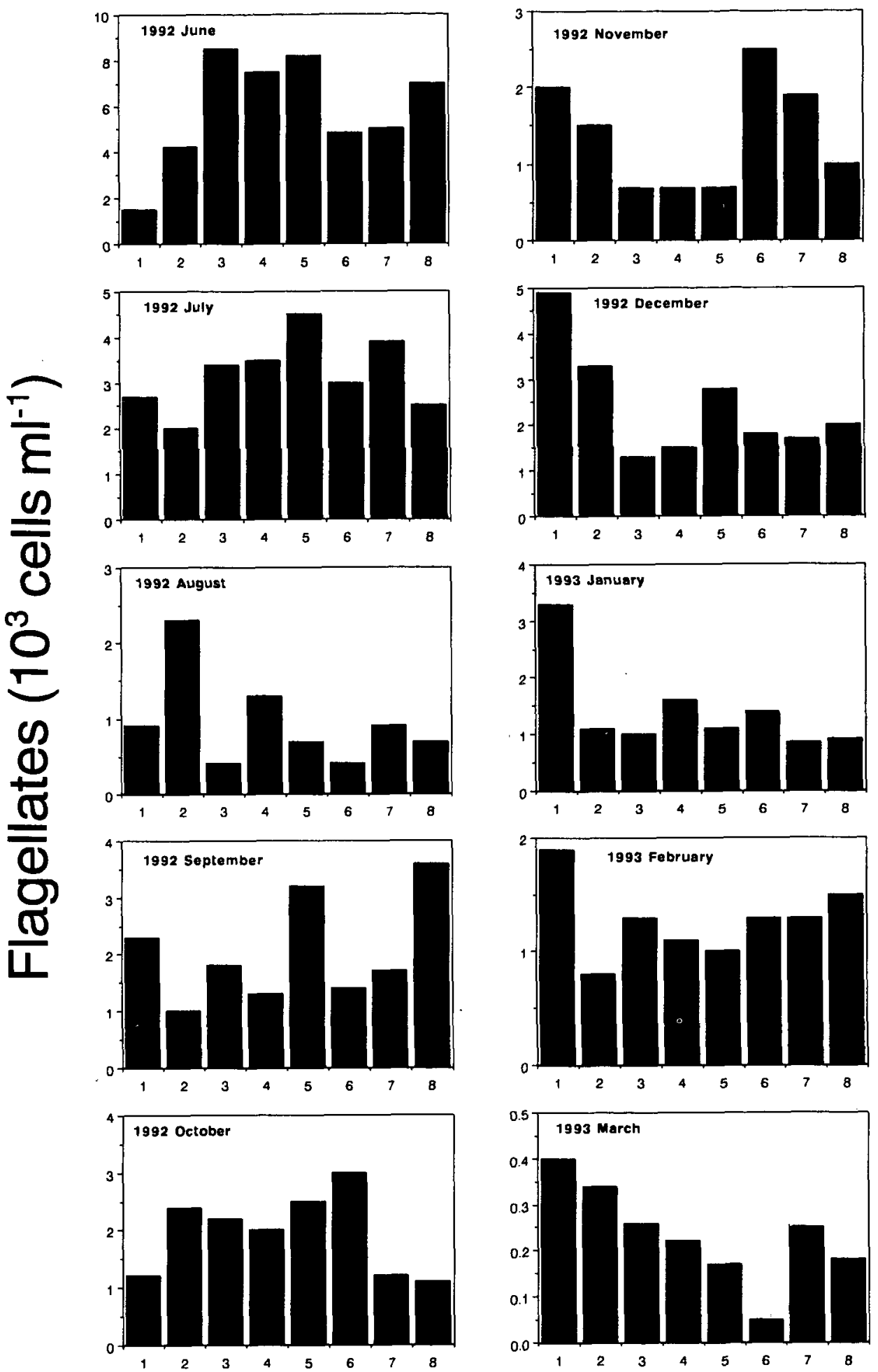

\section{Station}

Fig. 6. Horizontal distribution of heterotrophic flagellates during the survey period. 
levels were almost the same among stations (Figs. 2 and 3), the horizontal distribution of APP was variable during the summer and fall (Fig. 5). We compared the horizontal distribution of APP with that of flagellates (Fig. 6), but we could not find a consistent trend between them. As for the mortality of APP in lakes, not only the grazing of flagellates but also that of ciliates (WEISSE, 1988) and rotifers (CARON et al., 1985) as well as infection by viruses (MAEDA, 1995) may be also important. During warm weather, such biological activity could be high. The abundance and activity of these organisms should be determined in future studies.

\section{Acknowledgments}

We thank Mr. S. HoRII and the engineers of $R / V$ Mizusumashi II of the Shiga Prefectural Institute of Public Health and Environmental Science for their help in the field survey. Thanks are also due to Messrs. T. NAKAMURA and Y. YUKI for valuable discussions during the survey. We are also grateful to two anonymous reviewers for their comments on the earlier version of our manuscript.

\section{摘要 \\ 琵琶湖における超微細藻類の水平分布の 季節变化 : とくに水温, 栄養塩類, 従属栄養鞭毛虫との関連}

1992 年 6 月から 1993 年 3 月までの, 琵琶湖 8 定点における超微細落類 (algal picoplankton，以 下 APP) の現存量の水平分布の季節変化と, 従属 栄養鞭毛虫およびいくつかの環境要因のそれらと を対応させ, 琵琶湖の APP の消長について考察 した。水温预よび栄養塩類のレベルには, 定点間 の差はほとんど見られなかった。APP の細胞密度 の水平分布は, 夏期抢よび秋期には明瞭なパター ンは見いだされなかった。しかし，各定点におけ るAPP の細胞密度は, ほほ同一のパターンを示 した：APPは全ての定点において 8 月に最大の 細胞密度に達し, 冬期は細胞密度は低加た。夏 期と秋期に打ける従属栄養鞭毛虫の細胞密度の水 平分布には, APP と同様に明瞭なパターンは見ら れなかった。さらに, 各定点に拉ける鞭毛虫の細 胞密度の季節変化にも, 明瞭な傾向は得られなか
つた。

\section{References}

Bendschneider, K. and R. T. Robinson (1952) : A new spectrophotometric method for determination of nitrite in seawater. J. Mar. Res., 11:8796.

Bower, C. E. and T. Holm-Hansen (1980): A salicylate-hypochlorite method for determinating ammonia in seawater. Can. J. Fish. Aquat. Sci., $37: 794-798$.

CARon, D.A., F. R. PICK and D. R. S. LeAn (1985) : Chroococcoid cyanobacteria in Lake Ontario: vertical and seasonal distributions during 1982. J. Phycol., 21 : 171-175.

Ichise, S., T. Wakabayashi, S. Yamanaka, T. Sono, K. Naito, H. Kawabe, K. Maehata, K. TanaKa and K. Nomura (1991): Abnormal growth of picoplankton occurred in Lake Biwa -19891990- (1) Picoplankton and other plankton. Rep. Shiga Pref. Inst. Pub. Hlt. \& Environ. Sci., $26: 138-147$. (In Japanese).

MAEDA, H. (1995): Grazing and killer organism impact on picoplankton. Nippon Suisan Gakkaishi, 61 (in press) (In Japanese).

MaEda, H., A. KaWAi and M. M. Tilzer (1992): The water bloom of cyanobacterial picoplankton in Lake Biwa, Japan. Hydrobiologia, 248 : 93-103.

Murphy, J. and P. Riley (1962): A modified single solution method for the determination of phosphorus in natural waters. Anal. Chim. Acta, 27 : $31-36$.

Nagata, T. (1986): The seasonal abundance and vertical distribution of the $<3-\mu \mathrm{m}$ phytoplankton in the north basin of Lake Biwa. Ecol. Res., 7: 207-221.

NAGATA, T. (1988) : The microflagellate-picoplankton food linkage in the water column of Lake Biwa. Limnol. Oceanogr., 33 : 504-517.

Nagata, T., K. Takai, K. Kawabe, D.-S. KIm, R. Nakazato, N. Guselnikova, N. Bondarenko, $O$. Mologawaya, T. Kostrnova, V. Drucker, Y. SATOH and Y. WATANABE (1994): Autotrophic picoplankton in southern Lake Baikal : abun dance, growth and grazing mortality during summer. J. Plankton Res., 16 : 945-959.

Nakano, S., T. MiYajima, M. Nakanishi and Y. TEzUKA (1993): Abundance of algal picoplankton and heterotrophic flagellates in the south basin of Lake Biwa, with special attention to nutrient levels. Ann. Rept. Interdiscipl. Res. Inst. Environ. Sci., $12: 55-63$.

SHERR, E. B. and B. F. SHERR (1983) : Double-staining 
epifluorescence technique to assess frequency of dividing cells and bacterivory in natural populations of heterotrophic microprotozoa. Appl. Environ. Microbiol., 46 : 1388-1393.

SøndergaARD, M. (1991): Phototrophic picoplankton in temperate lakes: seasonal abundance and importance along a trophic gradient. Int. Revue ges. Hydrobiol., 76 : 505-522.

Stockner, J. G. and N. J. Antia (1986): Algal picoplankton from marine and freshwater ecosystems : a multidisciplinary perspective. Can. J. Fish. Aquat. Sci., $43: 2472-2503$.

Suttle, C. A. and P. J. Harrison (1988): Ammonium and phosphate uptake rates, $\mathrm{N}$ : $\mathrm{P}$ supply ratios, and evidence for $\mathrm{N}$ and $\mathrm{P}$ limitation in some oligotrophic lakes. Limnol. Oceanogr., $33: 186-202$.

TEzUKA, Y. (1984) : Seasonal variations of dominant phytoplankton, chlorophyll $a$ and nutrient levels in the pelagic regions of Lake Biwa. Jpn. J. Limnol., $45: 26-37$.

WEHR, J. D. (1989) : Experimental tests of nutrient limitation in freshwater picoplankton. Appl. Environ. Microbiol., 55 : 1605-1611.

WEISSE, T. (1988): Dynamics of autotrophic picoplankton in Lake Constance. J. Plankton Res., $10: 1179-1188$.
Wood, E., F. A. Armstrong and F. A. Richards (1967): Determination of nitrate in seawater by cadmium-copper production to nitrite. J. Mar. Biol. Ass. U. K., 47 : 22-31.

(著者：中野伸一, 滋賀県琵琶湖研究所, 干520大津 市打出浜 1-10；田中勝美, 園 正, 若林徹哉, 一瀬 諭, 山中 直, 金田恵美子, 矢田 稔, 内藤幹滋, 川 部浩市, 前畑佳代, 藤原直樹, 前田典子, 野村 潔, 滋賀県立衛生環境センター, テ520大津市御殿浜 1345 ; 中西正己, 京都大学生態学研究センター, テ520大 津市下坂本 4 丁目 1-23: Shin-ichi NaKaNo, Lake Biwa Research Institute, 1-10 Uchidehama, Otsu 520 ; Katsumi TanaKa, Tadashi Sono, Tetsuya WaKabayashi, Satoshi Ichise, Sunao YamanaKa, Emiko Kaneda, Minoru YadA, Mikishige NaITOH, Koichi Kawabe, Kayo MaEhata, Naoki Fujlwara, Noriko MAEDA, and Kiyoshi NomurA, The Shiga Prefectural Institute of Public Health and Environmental Science, 13-45 Midonohama, Otsu 520; Masami NaKANISHI, Center for Ecological Research, Kyoto University, 4-1-23 Shimosakamoto, Otsu 520)

Received : 11 May 1995

Accepted : 4 November 1995 